\title{
Language Attitudes of Young Generation of Mandar, a Minority Migrant Community in Desa Baharu Utara, Kotabaru Regency
}

\begin{abstract}
Alimuddin
STKIP PGRI Banjarmasin, Indonesia

aldin331966@gmail.com

ABSTRACT

This research is aimed to describe the language attitude of the people of Mandar, a migrant community in Desa Baharu Utara, Kotabaru Regency. The community group chosen as the object of the research is the young generation (Generasi Muda or GM) of Mandar. Therefore, the respondents are 40 people in various age groups consisting of children, adolescents, and adults with an age range of 6-45 years. Data collection of language attitudes was carried out using a questionnaire which was supported by field observations at the research location. It was found on the research location that GM is more proficient in Banjarese Language (Bahasa Banjar or BB) than Mandar (Bahasa Mandar or BM). This is based on the reality that BB is a local language with high prestige. On the other hand, $\mathrm{BB}$ has a strategic role as a lingua franca, which is the language of communication between ethnic groups in the Kotabaru area. Meanwhile, BM, which is the language of minority migrants from West Sulawesi, tends to be pushed by BB's domination because it has lost its prestige. As a result, BM experiences a shift from time to time which is feared to lead to extinction. The shift occurs at various linguistic levels, both phonemes, morphemes, and lexicon. The results of field observations indicate that the older generation (Generasi Tua or GT) has a more positive attitude towards BM than the GM of Mandar. The language attitudes include 1) pride in using BM, 2) loyalty to BM related to the level of frequency of using BM, and 3) awareness of BM norms related to linguistic norms and social norms related to BM usage situations and domains of use BM.
\end{abstract}

Keywords: language attitude, Mandar people, minority migrants

\section{INTRODUCTION}

The people of Mandar who live in Desa Baharu Utara (DBU) Kotabaru Regency are originally from a minority ethnic group who migrated from West Sulawesi in the 1950s. As a minority migrant group, the Mandar ethnic group have to come into contact with other migrants and local ethnic groups such as the Bajau (Sea Tribe), Bugis, Chinese, and Javanese. Each ethnic group utilizes its first language (B1) in interaction among its members. Meanwhile, interactions between different ethnic groups in informal situations tend to be done in Bahasa Banjar (Banjarese Language or BB), while Indonesian (BI) is chosen in formal situations. This shows that BB is a superior language that acts as a lingua franca used in inter-ethnic communication in Kotabaru. In addition, the Banjarese ethnic group whose BB is its local native language has the largest number of speakers. Based on field observations, it is indicated that BB is a high prestige language so that it is not only spoken by Banjarese but also non-Banjarese. This condition has implications for the language attitude of the Mandar community in DBU because the contact between languages is increasingly open. Moreover, the location of the DBU is still in the city centre of Kotabaru Regency which is classified as a multiethnic and multilingual area.

DBU as the centre of the Mandar ethnic settlement has a population of 6,771 people with 1,639 families [1]. It is estimated that $30 \%$ of the total population in DBU is Mandar ethnicity, while the rest consists of various ethnic groups which are dominated by Banjarese. The consideration is from $30 \%$ or 2,031 people of Mandar, only 1,200 people speak $\mathrm{BM}$, the rest choose $\mathrm{BB}$ in their interaction. The result is a decrease in $\mathrm{BM}$ speakers from time to time. This situation is of course exacerbated by the language attitude of the young generation (GM) of 
Mandar who tend to view $\mathrm{BB}$ as more prestigious than BM. Contrasted with the older generation (GT), which have a more positive attitude towards BM as shown by their consistency in the use of BM in the family domain.

Therefore, the focus of the research is on the language attitude of the GM of the Mandar community towards $\mathrm{BM}$ as a heritage language. Garvin and Mathiot [2] mention three aspects related to language attitudes, language pride, language loyalty, and language norms awareness. These three aspects are part of a positive language attitude [3]; [4]. Language pride is related to the desire of speakers or speech communities to make their language and ethnic identity and distinguish it from other ethnic groups. Language loyalty is related to the obedience of speakers or speech communities in preserving their language so that they can survive. Awareness of the existence of language norms is related to a conscious feeling of linguistic and social norms/rules that speakers should obey. Language attitudes can be positive or negative [5]; [6]) which are largely determined by speakers of a particular language. The behaviour of speakers upholding the use of their language is a sign of a positive attitude, while the low motivation of speakers to speak their language is a form of negative language attitudes.

The attitude of the speakers of a language will have great implications for the survival of the language. This is based on the fact that a positive attitude of the speakers of a language will facilitate the transmission of language between generations. On the other hand, the negative attitude of the speakers of a language will have an impact on the occurrence of language shifts. Therefore, language survival is a reflection of the language attitude of a society that consistently speaks its language so that it still exists. The attitude of the speakers of a language greatly determines language maintenance as the results of research by An et.al [7] link language attitudes, language proficiency, and the ethnic identity of the Pumi in Yunnan (China). The findings prove that language attitudes affect the variables of language proficiency level and ethnic identity in the Pumi ethnic minority group. However, another study conducted by Lakawa and Walaretina [8] showed somewhat different findings. Researchers report that the positive language attitude of the Betawi people in Jakarta is influenced by the strategy of the government and local communities to support and strengthen the Betawi ethnic identity in Jakarta. On this basis, it is clear that the factors that influence the language attitude of the speech community are not always the same as the results of research in various regions.

\section{METHODOLOGY}

In measuring the language attitude of GM Mandar towards BM, the researcher used a Likert scale questionnaire comprised of questions or statements that are measured by a positive scale and given a score. The range of responses there is five choices which include a score of $5=$ strongly agree (SS), a score of $4=$ agree $(\mathrm{S})$, a score of $3=$ uncertain (TP), a score of $2=$ disagree (TS), and a score of $1=$ strongly disagree (STS). The following interpretation criteria are presented as a reference: 1) $0 \%-20 \%=$ very weak, 2) $21 \%-40 \%=$ weak, 3) $41 \%-60 \%=$ moderate, 4) $61 \%-80 \%=$ strong, and 5) $81 \%-100 \%$ $=$ very strong. It is important to inform that the researcher bases GM language attitudes on three aspects, namely pride in $\mathrm{BM}$, loyalty to $\mathrm{BM}$, and awareness of BM norms (linguistic and social). To fulfil the aim and get valid data, in-depth interview data and participant observation will support the questionnaire data through recorded conversations got by tapping techniques from various speech events. The researcher adopted the observer's paradox (Labov's term in Wardhaugh, [9], namely observing the conversation without the speaker knowing. The source of data in this study was 40 people of GM Mandar, consisting of children, adolescents, and adults so that the age range of the respondents was 645 years. The researcher chose GM as the respondent based on the consideration that it is this group of Mandar people who show a language attitude that is not yet optimal towards the use of BM.

\section{ANALYSIS}

The data on the language attitude of the Mandar community that was captured included pride in BM, loyalty to BM, and awareness of BM norms related to linguistic norms and social norms. The researcher presented these three aspects in the following data analysis.

\subsection{Pride of $B M$}

GM's response concerning pride in BM related to a) pride in speaking $\mathrm{BM}, \mathrm{b}$ ) more proud to speak BM than other regional languages (BD), c) children's pride in choosing $\mathrm{BM}$ when talking with friends who master BM, d) youth pride in choosing BM when talks with his age and $\mathrm{f}$ ) the example of parents says $\mathrm{BM}$ when talking with the nuclear family in the house.

Regarding the pride of respondents using BM, the result showed a score of $64 \%$ which is a strong criterion. This means that respondents have pride in using BB even though in reality they are more likely to choose $\mathrm{BB}$. The same thing also applies to the statement of respondents who are more proud to say that their BM than other BDs scored $67.5 \%$ in the strong category. Here, respondents still consider BM to have an appeal when compared with other local languages. So even though mastering BM passively, it is difficult to forget $\mathrm{BM}$ as a legacy language. Related to the pride of children choosing BM when talking with friends who master $\mathrm{BM}$, the result showed a score of $53 \%$ which is sufficient. The score indicated that GM still has pride in BM to interact 
with playmates even though the score is not optimal. The attitude of this respondent proves that we can still say the transmission of inherited language between generations to be quite successful. Concerning the respondent's statement on controlling teenagers who are proud to choose $\mathrm{BM}$ when talking to fellow teenagers who master BM, a score of $54 \%$ is classified as sufficient criteria. The result of data analysis showed that respondents provide support for the use of BM among adolescents even though in reality they are more likely to choose $\mathrm{BB}$ when speaking with others who master BM. However, it can be interpreted that they still have concern for BM as the language inherited from their ancestral land. Respondent's statement to adults who are proud to use BM at their age. Obtained a score of $65.5 \%$ which is classified as a strong criterion. The level of score is following the facts on the ground which show that adults prefer to say BM when communicating with others who master BM. This means that respondents have a positive attitude in encouraging adults to keep trying to say BM. Another statement from respondents regarding parents being role models said that BM when talking with the nuclear family in the house got a score of $69.5 \%$ which was categorized as strong. This is under field observations that have shown that respondents have positive thoughts if parents often use BM in the household when interacting with the nuclear family. The selection of B1 in the family of course will make the relationship of family members more intimate.

Based on the explanation above, it can be emphasized that the age group of children and adolescents gave a positive response regarding the pride of saying BM. However, their responses were not in line with the language attitude shown in their daily life by preferring to speak BB in conversation in various domains. This implies that children and adolescents have more control over $\mathrm{BB}$ than $\mathrm{BB}$ so that in interacting they use BB. Maybe BB was chosen as a means of communication because it was more prestigious than BM. The language attitude is shown by most of the GM circles certainly affects the instability of BM in DBU because there is a shift from $\mathrm{BM}$ to $\mathrm{BB}$. Such conditions require serious attention so that BM does not experience continuous shifts. After all, children and adolescents belonging to GM Mandar play an important role as a determinant in inheriting BM into the next generation.

Adults are the only GM Mandar group who consistently use BM when interacting in various speech events with their speech partners who master BM. Using BM is carried out by adults with each other and the elderly. This proves that only adults from the GM group in the Mandar community consistently say BM. This means that the adult group not only claims to be proud and loyal to BM but is supported by their behaviour that upholds the use of $\mathrm{BM}$. Or the attitude component shown by adults is in line with the cognitive component and the conative component. The researcher classified this attitude of language among adults as a positive attitude to support the inheritance of BM to survive and be stable.

\subsection{Loyalty to BM}

GM's responses related to a) parental loyalty to BM with their peers, b) parental loyalty to using BM with guests of Mandar ethnicity, c) children's loyalty to using BM with relatives, d) loyalty among Mandar ethnicity using BM, and e) the loyalty of adolescents to use BM with their age who mastered BM is the basis of loyalty measurements.

Regarding the loyalty of parents to use BM when interacting with their peers or with guests of Mandar ethnicity, they get a score in a strong category. This is in line with the reality that the parents consistently chose BM as an example to GM. This habit is a positive language attitude related to the maintenance of BM in the migration destination area.

Regarding the loyalty of children using BM with relatives, they got a sufficient criterion score. Getting this score is certainly under the fact that their language behaviour or attitude is still low in which the use of $\mathrm{BB}$ is higher compared to $\mathrm{BM}$. However, children still have a sense of concern for BM as their mother tongue $(\mathrm{Bi})$ which must be passed down from generation to generation.

Meanwhile, the loyalty of fellow Mandar ethnic groups in using BM received a positive response from GM Mandar under a score of $66.5 \%$ which is strong criteria. This score shows that fellow Mandar ethnic groups view BM as an ethnic identity. It also suggests that $\mathrm{BM}$ is a preserved ethnic pride even though it is far from their ancestral land.

However, the loyalty of adolescents using BM with their peers who mastered BM got a score of $62 \%$ with strong criteria. However, the criteria obtained are not in line with the facts in the field because based on observations got information that teenagers prefer to use BB when talking to their peers even though they both master BM.

\subsection{BM's Norms Awareness.}

Regarding awareness of the BM norms, it is based on the BM response which includes a) the use of BM according to the norm, b) the use of BM in relaxed situations, c) the use of BM in Mandar community meetings in informal situations, $d$ ) the use of BM when talking to parents on informal situations, e) use of BM when meeting with relatives who control BM in casual situations, $\mathrm{f}$ ) use of $\mathrm{BM}$ when meeting Mandar people who control BM in public services, g) use of BM in the family/household, h) use of BM in events customs/cultural traditions, and i) the use of BM among other Mandar people who control $\mathrm{BM}$ in traditional markets. 
Statements related to the use of BM under the rules/norms got a score of $68.5 \%$, which is classified as strong. The data show that respondents have a positive attitude. They are aware of the need to use $\mathrm{BM}$ based on linguistic rules. Using BM in a relaxed situation got a score of $53.5 \%$, which includes sufficient criteria. The low score shows GMs are not fully aware that social language factors associated with relaxed situations allow the use of BM. Likewise, in meetings and informal situations, Mandar people use BM as a means of interaction between meeting participants. The use of BM among older people in informal situations is no exception.

Regarding the use of BM when meeting with relatives who can use $\mathrm{BM}$, it has a score of $59 \%$. The score is sufficient, which certainly proves that there is still a concern for $\mathrm{BM}$ in interactions between relatives. This is important so that $\mathrm{BM}$, which is a marker of ethnic identity, can still be a means of communication, especially with relatives/family wherever they are.

Next, the response to the statement regarding the use of BM when meeting Mandar people in public services is $58.5 \%$ which is an adequate criterion. Getting this score implies GM has not fully realized that in public services Mandar people can choose BM in their interaction. Meanwhile, in reality, based on field observations, fellow Mandar people spoke using BM when they meet at public services.

Furthermore, the family/household is a domain that should require the use of BM. This has the support of the respondents, proved by the acquisition of a score of $63 \%$ which is classified as strong. It is undeniable that the family domain is a place for informal early B1 learning. Therefore, it is the parent's responsibility to control the use of B1 as an inherited language in the family. Family holds the key to successful mother tongue inheritance.

Using BM in traditional events/cultural traditions is also very important to note. In traditional events or cultural traditions, it is still possible to use local languages as a medium of communication. Therefore, $\mathrm{BM}$ is very open to being developed in the domain of customs/cultural traditions of the Mandar community. If $\mathrm{BM}$ does not show its social role in the domain of family and cultural traditions, then it may have undergone a shift.

Finally, it is also necessary to explain the use of BM among Mandar people in traditional markets. Based on the responses of respondents, it has a score of $69.5 \%$ classified as a strong criterion. It is relevant because among the Mandar people themselves, using $\mathrm{BM}$ in traditional markets interaction is preferable. Even though the occurrence of code-mixing of $\mathrm{BB}$ and BI is common. This shows that foreign languages have a potent influence on BM.

Starting from the description above, it is important to point out that GM of Mandar (children, teenagers, and adults) have a similar view to use linguistic and social rules/norms as references when using BM. This view shows that GM Mandar has a positive awareness of the use of BM in line with linguistic and social norms.

However, those who consistently show positive behaviour are the adult age group. Besides conveying responses about the need for linguistic and social rules/norms to be applied in speaking, adults directly use BM. This connects the cognitive, affective, and conative components that appear with language attitudes. It is different with children and adolescents who have positive responses regarding the importance of language rules or norms but not supported by their application in speaking BM.

Adults and parents consistently choose BM when interacting with other members of ethnic Mandar in the family/household domain. Meanwhile, children and adolescents speak BB. The interesting and unique thing observed in family interactions is that parents still choose BM to talk to their children. The children (including teenagers) choose BB when speaking. This situation in the family naturally demands mastery of two languages, namely $\mathrm{BM}$ and $\mathrm{BB}$, so that all family members are bilingual speakers. The concept bilingual here does not always refer to speakers who have a balanced mastery of two languages. However, it also applies to bilingual speakers who have passive language skills in one of the two languages they master. For example, a Mandar child prefers to speak $\mathrm{BB}$ in his family because the language is more actively mastered than BM.

The language attitude shown by an adult and elderly speakers towards BM is another thing to explain. Both age groups have a positive attitude regarding BM. this happens in the family domain and various wider domains. The BM statements given by these two groups with different age levels, apart from having pride and loyalty in using BM, have an awareness of applying the norms in BM. This proves that they have an important contribution to play in expanding the social role of DM so that it can survive and sustain its use amid threats and pressure from BB.

\section{CONCLUSION}

By observing the results of the research through the analysis described previously, the conclusion is that GT of Mandar has a more positive attitude towards BM than GM. Here, although the GM group has a passive mastery of BM, they still have a sense of pride and concern for BM as a legacy to transmit to the next generation. Likewise, regarding loyalty to $\mathrm{BM}$, the respondents comprising children, adolescents, and adults admitted remaining loyal to BM.

The acquisition of scores reveals criteria from moderate to strong. Related to awareness of the existence of BM norms/rules, respondents are fully aware of the importance of linguistic norms as a 
reference in explaining BM. However, they are less aware of the importance of language social norms as the consideration in using BM. Regarding social norms; it is common for the social role of BM to be expanded in various domains, not only the family domain but also to other domains such as customs/cultural traditions, transactions in traditional markets, and public services. We must carry this determination out so that the existence of $\mathrm{BM}$ continues to exist amid threats from other languages.

\section{ACKNOWLEDGMENT}

This article would not have been possible without the help of various parties. Therefore, the researchers would like to thank the research supervisor Prof. Dr Kisyani Laksono, M. Hum. and Dr Budinuryanta Yohanes, M. Pd. Thanks are also extended to the informants and respondents who have taken the time to answer the interview questions and questionnaires cooperatively.

\section{REFERENCES}

[1] Badan Pusat Statistik (BPS). (2017). Kecamatan Pulau Laut Utara dalam Angka.Kotabaru.

[2] Garvin, PL and Mathiot, M. (1968). "The Urbanization of The Guarani Language: A Problem in Language and Culture". In JA Fishman (Ed). Reading in The Sociology of Language, 365-374. Berlin, Boston: De
Gruyter.

[3] Chaer, A. dan Agustina L. (2004). Sosiolinguistik: Perkenalan Awal. Jakarta: Rineka Cipta

[4] Sumarsono dan Partana, P. (2004). Sosiolinguistik. Yogyakarta: Sabda.

[5] Jendra, MII (2012). Sociolinguistics: The Study of Societies' Languages. Yogyakarta: Graha Ilmu

[6] Rokhman, F. (2013). Sosiolinguistik: Suatu Pendekatan Pembelajaran Bahasa dalam Masyarakat Multikultural. Yogyakarta: Graha Ilmu.

[7] An, J., Wanner, PJ, Yu, J., and Ono, N. (2017). "Ethnic Identity, Language Use and Language Attitude of the Pumi in Yunnan, China". In International Journal of Language and Linguistics. Vol. 4 No. 4 December 2017, 259267. Online publications. www.Ijllnet.com

[8] Lakawa, AR and Walaretina, R. (2016). "The Influance of Attitude on The Maintenance of Betawi Language and Architecture". In Asian Journal of Social Science \& Humanities, vol. 5(3), 89-101. Online publication. www.ajssh.leena-luna.co.jp

[9] Wardhaugh, R. (1988). An Introduction to Sociolinguistics. Oxford: Basil Blackwell. 